\title{
TEKNOLOGI PEMBELAJARAN (DEMONSTRASIONAL) UNTUK MENINGKATKAN PEMAHAMAN MATERI HAKIKAT DEMOKRASI PANCASILA PADA MATA PELAJARAN PKN SISWA KELAS X-4 SMA NEGERI 1 PADALARANG TAHUN PELAJARAN 2011-2012
}

\author{
Asep Deta Saepudin \\ SMAN 1 Padalarang Kabupaten Bandung Barat \\ asepdeta59@yahoo.com
}

\begin{abstract}
This research focuses on improving the understanding of material nature effort Pancasila democracy on the subjects of Citizenship Education through Learning Technology (Demonstrate). The problems of this study include: (1) how concrete actions in improving understanding of the nature of matter in the eyes of Pancasila democracy lesson Citizenship Education through Learning Technology (Demonstration) in class X-4 SMAN 1 Padalarang West Bandung Regency 2011-2012 school year? And (2) whether the effort to improve understanding of the nature of the materials on the subjects of Pancasila democracy through technology learning Citizenship Education (Demostrasional) in class X-4 SMAN 1 Padalarang West Bandung Regency 2011-2012 school year to show improvement? Based on data analysis, activity and improved performance of the students obtained data showing that at the meeting with 20 students from the first cycle increased by $54 \%$ to $64.75 \%$ in the second cycle, the third cycle increased to $72 \%$. Analysis From these data, it can be said that the PBM activities performed quite effective in improving student learning outcomes. The conclusion of this study indicates that the application of the Demonstration method to improve the understanding of the matter: "The essence of Pancasila democracy" in the Subject Civics students of SMAN 1 Padalarang West Bandung Regency 2011-2012 school year has been successful and positive change. Significant.
\end{abstract}

Keywords: Demonstrate Pancasila Democracy, Citizenship Education

\section{A. PENDAhuluan}

Seorang guru adalah tenaga profesional yang berperan sebagai pengelola aktivitas yang harus bekerja berdasarkan pada kerangka acuan pendekatan manajemen pembelajaran. Guru harus memiliki, memahami dan terampil dalam menggunakan bermacam-macam pendekatan dalam manajemen pembelajaran supaya bisa menyesuaikan dalam menangani kasus manajemen dalam proses pembelajaran yang tepat dengan masalah yang dihadapinya.Pendapat ini dikemukakan oleh Brophy dan Evertson dalam Learning from Teaching, tahun 1976.
Guru yang melaksanakan manajemen pembelajaran sebagai proses pemapanan dan pemeliharaan (establishing and maintaining) lingkungan belajar yang efektif cendrung lebih sukses dari pada guru-guru yang memposisikan atau memerankan diri sebagai figure otoritas atau penegak disiplin (authority figures or disciplinarians) belaka.

Peranan kreativitas kompetensi akademik dari seorang guru mata pelajaran PPKn bisa sangat didambakan. Hal ini dilakukan sematamata untuk mencoba, menafsirkan, mengkonfirmasikan, meluruskan dan 
menyampaikan pencercahan, secara adaptif situasional, serta memberikan bimbingan secara moral, social, cultural dengan berbagai pendekatan yang dapat menciptakan keharmonisan dalam bimbingan dan pembinaan untuk:

1. Menciptakan kesadaran guru tentang tanggung jawabnya terhadap pelaksanaan kualitas proses pembelajaran;

2. Membantu guru untuk mengembangkan sikap positif dalam mengembangkan diri secara berkelanjutan; dan

3. Menciptakan keharmonisan dalam komunikasi dengan kolaboratif yang kondusif.

Berdasarkan kajian di atas, penulis tertarik untuk menyusun suatu karya Penelitian Tindakan Keguru mata pelajaran PPKn dengan judul " Tekhnologi Pembelajaran(Demonstrasional) Untuk Meningkat-kan Pemahaman Materi Hakikat Demokrasi Pancasila Pada Mata Pelajaran Pendidikan Kewarganegaraan Siswa Kelas X4 SMA Negeri 1 Padalarang Tahun Pelajaran 2011-2012".

\section{Pembatasan dan Rumusan Masalah}

Mengingat sangat Iuasnya permasalahan, maka dalam penelitian ini penulis batasi pada masalah yang dirumuskan sebagai berikut:

a. Bagaimana peningkatan kinerja Guru Mata Pelajaran PPKn dalam meningkatkan pemahaman materi hakikat demokrasi Pancasila Pada Pelajaran PPKn melalui kreativitas kompetensi akademik pada sekolah binaan di SMA Negeril Padalarang Kabupaten Bandung Barat tahun ajaran 2011-2012?

b. Bagaimana efektifitas peningkatan kinerja Guru Mata Pelajaran PPKn dalam meningkatkan pemahaman materi hakikat demokrasi Pancasila Pada Pelajaran PPKn melalui kreativitas kompetensi akademik padasekolah binaan di SMA Negeri 1
Padalarang Kabupaten Bandung Barat tahun ajaran 2011-2012?

\section{Hipotesa Tindakan}

Adapun hipotesa tindakan pada penelitian ini dinyatakan sebagai berikut:

a. Penerapan dan pelaksanaan kreativitas kompetensi akademik dapat mengembangkan dan meningkatkan kinerja guru dalam meningkatkan pemahaman materi hakikat demokrasi Pancasila Pada Pelajaran PPKn;

b. Penerapan dan pelaksanaan kreativitas kompetensi akademik dapat mengembangkan dan meningkatkan aktivitas kinerja Guru Mata Pelajaran PPKn dalam meningkatkan pemahaman materi hakikat demokrasi Pancasila Pada Pelajaran PPKn; dan

c. Penerapan dan pelaksanaan kreativitas kompetensi akademik dapat mengembangkan dan meningkatkan efektivitas kinerja Guru Mata Pelajaran PPKn dalam meningkatkan pemahaman materi hakikat demokrasi Pancasila Pada Pelajaran PPKn.

\section{Tujuan Penelitian}

Tujuan Utama dari Penelitian ini adalah:

a. Meningkatan dan memotivasi kinerja Guru Mata Pelajaran PPKn dalam mengembangkan meningkatkan pemahaman materi hakikat demokrasi Pancasila Pada Pelajaran PPKn melalui Demonstrasional.

b. Mengefektivitaskan implementasi kreativitas kompetensi akademik dalam peningkatan kinerja Guru Mata Pelajaran PPKn Dalam pemahaman materi hakikat demokrasi Pancasila.

\section{Manfaat Penelitian}

a. Bagi Guru: Para guru akan termotivasi untuk melaksanakan tugas pokok dan fungsinya secara proporsional dan profesional. 
b. Bagi Siswa: Termotivasi untuk menggali, mengarahkan, dan megembangkan kemampuan dasar yang harus dimilikinya.

c. Bagi Sekolah Mampu meningkatkan mutu pembelajaran di sekolah, dalam menggapai visi.dan misi sekolah.

d. Bagi Peneliti/Guru mata pelajaran PPKn: 1) Sebagai bahan refleksi terhadap program pembinaan guru mata pelajaran PPKn melalui Teknologi Pembelajaran Demonstrasional guru mata pelajaran PPKn; dan 2) Hasil penelitian ini diharapkan dapat memberikan kontribusi pada hasanah pengetahuan yang berkaitan dengan teori kepemimpinan/leadership terutama manajemen sekolah.

\section{Ruang Lingkup Kegiatan Penelitian}

Kegiatan penelitian ini dibatasi dalam sebuah ruang Iingkup penelitian sebagai berikut:

a. Kegiatan penelitian tindakan kelas (PTK) ini dilaksanakan di kelas X4 SMA Negeri 1 Padalarang Kabupaten Bandung Barat tahun pelajaran 20112012; dan

b. Pembelajaran difokuskan pada upaya peningkatan pemahaman materi hakikat demokrasi Pancasila melalui Teknologi Pembelajaran (Demonstrasional) dalam mata pelajaran Pendidikan Kewarganegaraan.

\section{Asumsi Dasar}

Pola kerangka asumsi penelitian yang mendasar dan prosedural yang digunakan dalam penelitian tindakan kelas (PTK) ini, meliputi:

a. Siswa kelas X-4 SMA Negeri 1 Padalarang Kabupaten Bandung Barat Tahun ajaran 2011-2012 cenderung menunjukan pemahaman dalam kegiatan pembelajaran (KBM) mata pelajaran PendidikanPPKn yang relatif kurang, khususnya materi hakikat demokrasi pancasila; dan

b. Guru bidang mata pelajaran PPKn relatif belum memiliki daya kreatifitas dalam pengelolaan kegiatan pembelajarn khususnya dalam meningkatkan pemahaman materi hakikat demokrasi Pancasila.

\section{B. KAJIAN LITERATUR}

\section{a. Penelitia Tindakan Kelas (PTK)}

Penelitian tindakan kelas merupakan bagian dari penelitian tindak (action research) yang dilakukan di lingkungan sekolah.Penelitian tindakan kelas (PTK) atau Classroom Action Research adalah bentuk penelitian yang bersifat reflektif dengan melakukan tindakan-tindakan tertentu agar dapat memperbaiki dan atau meningkatkan praktek-praktek pembelajaran di kelas secara profesional (Suyanto, 2003:121). Mc. Niff, Lomax dan Whitehead (2003) mengemukakan beberapa syarat keberhasilan Penelitian Tindakan

Kelas (PTK). Beberapa syarat tersebut meliputi: Pertama, guru serta murid harus punya tekad dan komitmen untuk meningkatkan kualitas pembelajaran secara proporsional. Kedua, guru menjadi pusat dari penelitian sehingga dituntut untuk bertanggung jawab atas peningkatan yang akan dicapai. Ketiga, tindakan yang guru lakukan hendaknya didasarkan pada pengetahun. Keempat, tindakan tersebut dilakukan atas dasar komitmen kuat dan keyakinan bahwa situasi dapat diubah ke arah perbaikan. Kelima, penelitian tindakan melibatkan pengajuan pertanyaan agar dapat melakukan perubahan melalui tindakan 
yang disadari dalam konteks Keenam, guru mesti memantau secara sistematik. Ketujuh, guru perlu membuat deskripsi otentik objektif (bukan penjelasan) . Kedelapan, guru perlu memberi penjelasan tentang tindakan berdasarkan deskripsi autentik. Kesembilan, guru perlu menyajikan laporan hasil PTK Kesepuluh, guru perlu memvalidasi pernyataan tentang keberhasilan.

Grundy \& Kemmis (1982: 84) mengemukakan tujuan utama Penelitian Tindakan Kelas (PTK) adalah untuk mengubah perilaku pengajaran guru, perilaku murid-murid di kelas, dan/atau mengubah kerangka kerja melaksanakan pembelajaran kelas.PTK berfungsi sebagai alat untuk meningkatkan kualitas pelaksanaan pembelajaran kelas. Di ruangan kelas, PTK dapat berfungsi (Cohen \& Manion, 1980: 211): (a) alat untuk mengatasi masalahmasalah yang didiagnosis dalam situasi pembelajaran di kelas; (b) alat pelatihan dalam-jabatan, membekali guru dengan keterampilan dan metode baru dan mendorong timbulnya kesadarandiri, khususnya melalui pengajaran sejawat; (c) alat untuk memasukkan ke dalam sistem yang ada (secara alami) pendekatan tambahan atau inovatif; (d) alat untuk meningkatkan komunikasi yang biasanya buruk antara guru dan peneliti; dan (e) alat untuk menyediakan alternatif bagi pendekatan yang subjektif, impresionistik terhadap pemecahan masalah kelas.

PTK bersifat transformatif, maka kriteria yang cocok adalah validitas demokratik, validitas hasil, validitas proses, validitas katalitik, dan validitas dialogis, yang harus dipenuhi dari awal sampai akhir penelitian, yaitu dari refleksi awal saat kesadaran akan kekurangan muncul sampai pelaporan hasil penelitiannya (Burns, 1999: 161162, menyitir Anderson dkk,1994).

PTK memiliki kelebihan berikut (Shumsky, 1982): (1) tumbuhnya rasa memiliki melalui kerja sama dalam PTK; (2) tumbuhnya kreativitias dan pemikiran kritis lewat interaksi terbuka yang bersifat reflektif/evaluatif dalam PTK; (3) dalam kerja sama ada sating merangsang untuk berubah; dan (4) meningkatnya kesepakatan lewat kerja sama demokratis dan dialogis dalam PTK (silakan lihat Passow, Miles, dan Draper, 1985). Agar PTK berhasil, persyaratan berikut harus dipenuhi; (Hodgkinson, 1988): (1) kesediaan untuk mengakui kekurangan din: (2) kesempatan yang memadai untuk menemukan sesuatu yang baru; (3) dorongan untuk mengemukakan gagasan baru; (4) waktu yang tersedia untuk melakukan percobaan; (5) kepercayaan timbal balik antar orang-orang yang terlibat; dan (6) pengetahuan tentang dasardasar proses kelompok oleh peserta penelitian.

\section{b. Metode Demonstrasi}

Meningkatkan prestasi belajar siswa merupakan sebuah merupakan sebuah usaha yang dilakukan antara beberapa pihak yang terkait dalam pengembangan dan pengelolaan pendidikan, seperti guru, orang tua siswa (wali murid), dan pihak-pihak yang lainnya (Suryaman, 1990: 12). Metode demonstrasi merupakan suatu metode pendekatan untuk meningkatkan kemampuan dan keterampilan siswa untuk melakukan beberapa kegiatan praksis yang didasasi tindak imitatif terhadap lakuan guru yang menitikberatkan kegiatan pada penyampaian material pembelajaran yang dikemas (Wahyudi, 1992:22). 


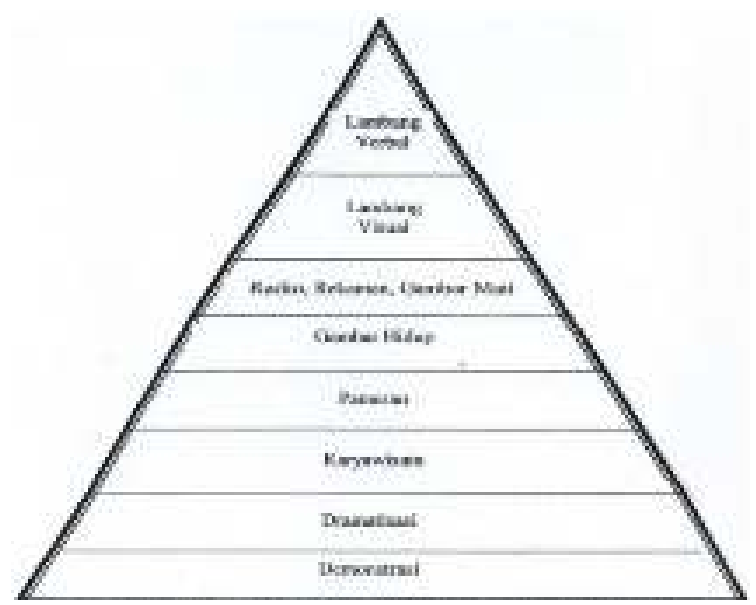

Gambar 1

Kerucut Pengalaman Belajar

Sumber: Edgar Dale, 1989

\section{c. Teknologi Pembelajaran}

Edgar Dale dan James Finn merupakan dua tokoh yang berjasa dalam pengembangan Teknologi Pembelajaran modern. Edgar Dale mengemukakan tentang Kerucut Pengalaman (Cone of Experience).

Pemikiran Edgar Dale tentang Kerucut Pengalaman (Cone of Experience) ini merupakan upaya awal untuk memberikan alasan atau dasar tentang keterkaitan antara teori belajar dengan komunikasi audiovisual.Kerucut Pengalaman Dale telah menyatukan teori pendidikan John Dewey (salah satu tokoh aliran progresivisme) dengan gagasan-gagasan dalam bidang psikologi yang tengah populer pada masa itu.

Sedangkan, James Finn seorang mahasiswa tingkat doktoral dari. Gagasan Finn mengenai terintegrasinya sistem dan proses mampu mencakup dan memperluas gagasan Edgar Dale tentang keterkaitan antara bahan dengan proses pembelajaran. Definisi menurut AECT
1994, teknologi pembelajaran adalah teori dan praktek dalam desain, pengembangan, pemanfaatan, pengelolaan, serta evaluasi tentang proses dan sumber untuk belajar.

a. Definisi Commission on Instruction Technology (C17) 1970. Dalam pengertian yang lebih umum, teknologi pembelajaran diartikan sebagai media yang lahir sebagai akibat revolusi komunikasi yang dapat digunakan untuk keperluan pembelajaran di samping guru, buku teks, dan papan tulis, bagian yang membentuk teknologi pembelajaran adalah televisi, film, OHP, komputer dan bagian perangkat keras maupun lunak lainnya.

B.F. Skinner (salah seorang tokoh Psikologi Behaviorisme) dalam teknologi pembelajaran. Begitu juga, rumusan tersebut memandang pentingnya penelitian tentang metode dan teknik yang digunakan untuk mencapai tujuan khusus.

b. Definisi Silber 1970. Teknologi Pembelajaran adalah pengembangan (riset, desain, produksi, evaluasi, dukungan pasokan, pemanfaatan) komponen sistem pembelajaran (pesan, orang, bahan, peralatan, teknik dan latar) serta pengelolaan usaha pengembangan (organisasi dan personal) secara sistematik, dengan tujuan untiik memecahkan masalah belajar. Definisi yang dikemukakan oleh Kenneth Silber di atas menyebutkan istilah pengembangan.Pada definisi 
sebelumnya yang dimaksud dengan pengembangan lebih diartikan pada pengembangan potensi manusia. Dalam definisi Silber, penggunaan istilah pengembangan memuat dua pengertian, disamping berkaitan dengan pengembangan potensi manusia juga diartikan pula sebagai pengembangan dari Teknologi Pembelajaran itu sendiri, yang mencakup: perancangan, produksi, penggunaan dan penilaian teknologi untuk pembelajaran.

c. Definisi MacKenzie dan Eraut 1971. Teknologi Pendidikan merupakan studi sistematik mengenai cara bagaimana tujuan pendidikan dapat dicapai". Definisi sebelumnya meliputi istilah, "mesin", instrumen" atau "media", sedangkan dalam definisi MacKenzie dan Eraut ini tidak menyebutkan perangkat lunak maupun perangkat keras, tetapi lebih berorientasi pada proses.

d. Definisi AECT 1972 pada tahun 1972, AECT berupaya merevisi definisi sudah ada (1963, 1970, 1971), dengan memberikan rumusan sebagai berikut: Teknologi Pendidikan adalah suatu bidang yang berkepentingan dengan memfasilitasi belajar pada manusia melalui usaha sistematik dalam: identifikasi, pengembangan,

pengorganisasian dan pemanfaatan berbagai macam sumber belajar serta dengan pengelolaan atas keseluruhan proses tersebut. e. Definisi AECT 1977. Teknologi pendidikan adalah proses kompleks yang terintegrasi meliputi orang, prosedur, gagasan, sarana, dan organisasi untuk menganalisis masalah, merancang, melaksanakan, menilai dan mengelola pemecahan masalah dalam segala aspek belajar pada manusia.

\section{d. Pengertian Belajar}

Winkel (1987:82) mengatakan bahwa belajar adalah interaksi yang aktif antara individu dengan Iingkungan sosialnya yang menghasilkan perubahan dalam pengetahuan, kemampuan, pemahaman, dan sikap.Perubahan tersebut bersifat konstan dan berbekas. Perubahan-perubahan yang terjadi pasca kegiatan belajar tidak hanya bersifat fisis tetapi juga menyentuh ranah spiritual. Sudjono (1980:81) mengatakan bahwa mengajar adalah suatu kegiatan mengubah situasi pribadi siswa dalam pemupukan pengertian, pengetahuan, dalam mengembangkan daya-daya jiwa, sikap, serta keterampilan, dan sebagainya. Menurut Suryabrata (1984:39) mengatakan bahwa, prestasi memiliki pengertian sebagai suatu bentuk kemajuan yang telah dicapai, pada umumnya dapat memberikan pengaruh pada kualitas pekerjaan atau kegiatan kegiatan berikutnya.

\section{METODE PENELITIAN}

Kegiatan penelitian "Teknologi pembelajaran (Demonstrasional) untuk meningkatkan pemahaman materi hakikat 
demokrasi Pancasila pada matapelajaran pendidikan Kewarganegaraan siswa kelas X-4 SMA Negeri 1 Padalarang tahun pelajaran 2011-2012" ini menggunakan kaidah-kaidah prosedur penelitian tindakan kelas.

\section{Rancangan Penelitian}

Kegiatan penelitian ini tercakup dalam dua siklus danterdiri dari dua kali pertemuan. Siklus pertama dilaksanakan pada pertemuan pertama, sedangkan siklus ke dua pada pertemuan ke dua.Siklus pertama dilaksanakan pada tanggal 10 februari 2012. Siklus ke dua dilaksanakan pada tanggal 18 februari 2012. Secara rinci, tahapan masingmasing siklus dalam proses penelitian ini dapat dicermati di bawah ini, yang meliputi:

a. Siklus Pertama

1) Penyampaian sosialisasi awal;

2) Guru menyampaikan materi melalui teknologi, pembelajaran

(Demonstrasional);

3) Guru menyampaikan dan memberikan penugasan berupa kegiatan praktek dan latihan soal;

4) Evaluasi pertama.

b. Siklus ke dua
1) Guru pengajaran remedial; memberikan
2) Guru memberikan penugasan ke dua berupa kegiatan praktek dan latihan soal;
3) Evaluasi ke dua; dan
4) Simpulan

\section{Tempat Penelitian}

Kegiatan penelitian ini dilaksanakan di kelas X-4 SMA Negeri 1 Padalarang Kabupaten Bandung Barat tahun ajaran 20112012.

\section{Instrumen Penelitian}

Instrumen utama penelitian tindakan kelas (PTK) adalah peneliti itu sendiri,.seluruh realitas data dan bagaimana upaya-upaya menyikapi dan menganalisisnya. Untuk mendukung dan melengkapi instrumen utama digunakanlah instrumen penunjang. Instrumen penunjang tersebut meliputi: (a) pedoman observasi; (b) catatan lapangan; (c) dokumentasi; dan (d) foto.

\section{Proses Analisis Data}

Rofiudin dam Sukoco (2002:120 mengatakan bahwa data utama yang dianalisis adalah data verbal dari peneliti sendiri, yang berupa gambaran terperinci dari proses dan hasil belajar siswa. Sedangkan, data penunjang meliputi data dari hasil observasi record. Pedoman analisis proses pembelajaran dalam kegiatan penelitian tindakan kelas (PTK) tekhnologi pembelajaran (Demonstrasional) untuk meningkatkan pemahaman materi hakikat demokrasi pancasila pada mata pelajaran PPKn Kelas X-4 SMA Negeri 1 Padalarang tahunPelajaran 2011/2012 ini dilakukan dengan menggunakan tabel 3.1 berikut ini. 
Tabel 1

Pedoman Analisis Proses Belajar Siswa

\begin{tabular}{|c|c|c|c|}
\hline \multirow{2}{*}{ 筮陌 } & \multirow{2}{*}{ (th } & 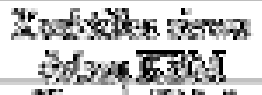 & \multirow{2}{*}{ 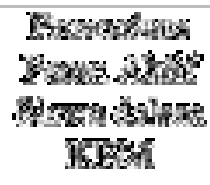 } \\
\hline & & 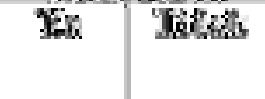 & \\
\hline \multirow[t]{5}{*}{8} & 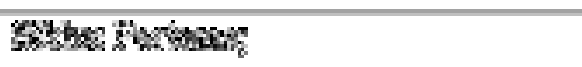 & & \\
\hline & 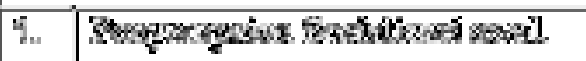 & & \\
\hline & 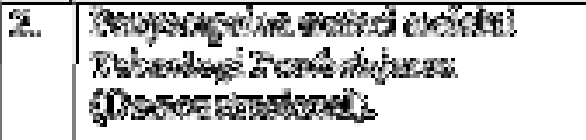 & & \\
\hline & 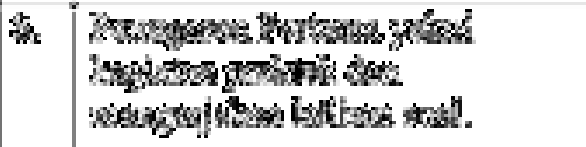 & & \\
\hline & 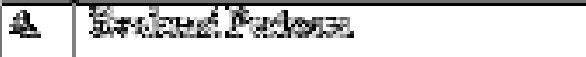 & & \\
\hline 초. & 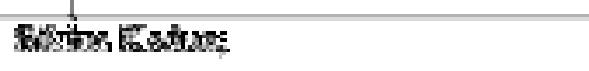 & & \\
\hline & 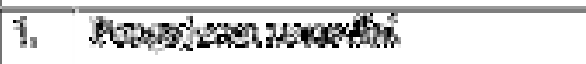 & & \\
\hline & 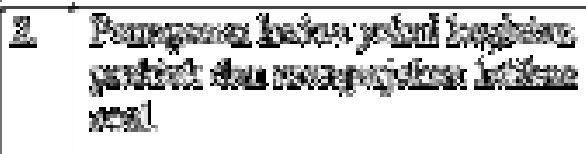 & & \\
\hline & 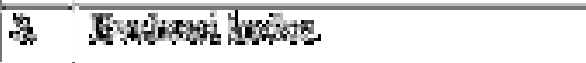 & & \\
\hline & 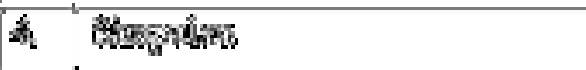 & & \\
\hline
\end{tabular}

Kegiatan penganalisisan data dan penyimpulan hasil penelitian tindakan kelas (PTK) ini ditentukan dengan standar prosentase keberhasilan penelitian sebagai berikut:

a. Tingkat pemahaman siswa pada materi hakikat demokrasi Pancasila pada Mata Pelajaran Pendidikan Kewarganegaraan secara individual dinilai dari produk kegiatan penugasan yang bersifat evaluatif pada siklus pertama dan siklus kedua dan pengamatan selama kegiatan pembelajaran sepanjang siklus berlangsung adalah sekurang-kurangnya

mendapatkan nilai 75 atau pencapaian nilai dari siswa rata-rata sekurang-kurangnya 85 atau persentase pencapaian ratarata $85 \%$.

b. Persentase keterlibatan aktif siswa dalam prosedur 
pembelajaran secara

individual yang berlangsung sepanjang siklus, baik siklus pertama, kedua dan ketiga adalah sekurang-kurangnya $75 \%$ atau persentase keberhasilan pencapaian dari masing-masing siswa ratarata sekurangkurangnya 85 $\%$.

c. Persentase kemampuan siswa dalam mengerjakan tugas yang diberikan secara individual sekurangkurangnya $75 \%$ atau persentase keberhasilan pencapaian dari masingmasing siswa rata-rata sekurangkurangnya $85 \%$.

\section{HASIL DAN PEMBAHASAN}

\section{SIKLUS I}

Paparan Data dan Temuan Penelitian

a. Perencanaan Tindakan

Penelitian ini menggunakan pendekatan Teknologi

Pembelajaran Demonstrasional pada mata pelajaran Pendidikan Kewarganegaraan bagi siswa Kelas X-4 SMA Negeri 1 Padalarang Kabupaten Bandung Barat.Tujuan yang diharapkan pada pertemuan pertama dalam penelitian ini adalah untuk meningkatkan prestasi hasil pembelajaran bagi siswa Kelas X-4 SMA Negeri 1 Padalarang Kabupaten Bandung Barat.

Agar tercapai tujuan di atas, peneliti yang bertindak sebagai siswa mata pelajaran PPKn X-4 SMA Negeri 1 Padalarang Kabupaten Bandung Barat melakukan IangkahIangkah mencakup: Menyusun RPP,
Menyusun instrumen data angket, Sosialisasi kepada siswa Kelas X-4, Melaksanakan tindakan dalam pembinaan, Melakukan refleksi, Menyusun strategi pembelajaran pada siklus ke dua berdasarkan refleksi siklus pertama, Melaksanakan pem-belajaran pada siklus ke dua, Melakukan observasi, Melakukan refleksi pada siklus ke dua, Menyusun strategi pembelajaran pada siklus ke tiga berdasarkan refleksi siklus ke dua, Menyusun Pelaksanaaan pembelajaran oleh peneliti berdasar refleksi pada siklus II, melakukan pem-belajaran melalui Teknologi Pembelajaran Demonstrasional pada siklus ke III, Melakukan observasi, Melakukan refleksi pada siklus III dan Menyusun laporan.

b. Pelaksanaan Tindakan dan Pengamatan

Pelaksanaan tindakan kelas dalam penelitian dilakukan 3 siklus yang terdiri dari tiga kali pertemuan. Waktu yang digunakan setiap kali pertemuan adalah 2 x 60 menit. Pertemuan pertama dilaksanakan pada tanggal 10 Februari 2012 sampai dengan tanggal 14 Februari 2012, dan pertemuan ke dua pada tanggal 15 Februari 2012 sampai dengan tanggal 16 Februari 2012, pertemuan ke tiga pada tanggal 17 Februari 2012 sampai dengan tanggal 18 Februari 2012. Penelitian tindakan Pembelajaranan dilaksanakan sesuai dengan prosedur rencana pembelajaran dan skenario 
pembelajaran. Berikut adalah siklus ke-1, dengan langkah:

1) Tahap Perencanaan. Pada tahap ini peneliti mempersiapkan perangkat observasi berupa lembar observasi pencapaian nilai hasil pembelajaran, pelaksanaan pembelajaran yang sudah distandarisasi dan alat-alat pengajaran lain yang mendukung.

2) Tahap Kegiatan dan Pelaksanaan. Pelaksanaan kegiatan penelitian untuk siklus I dilaksanakan pada tanggal 10 Februari 2012 sampai dengan tanggal 14 Februari 2012 di Kelas X-4 SMA Negeri 1 Padalarang Kabupaten Bandung Barat tahun ajaran $2011-2012$, dengan jumlah siswa 20 siswa. Dari tabel dapat dijelaskan bahwa dengan pembelajaran secara konvensional diperoleh nilai rata-rata $54 \%$, atau ada 4 orang siswa dari 20 orang siswa sudah tuntas. Hasil tersebut menunjukan bahwa pada siklus pertama secara keseluruhan belum tuntas, karena sisiwa yang memperoleh nilai $>65$ hanya sebesar $20 \%$ Iebih kecil dari prosentase ketuntasan yang dikehendaki yaitu sebesar 85 $\%$. Hal ini disebabkan karena siswa masih merasa baru dan belum mengerti apa yang dimaksudkan dan fungsi dari penerapan Teknologi

Pembelajaran

Demonstrasional. c. Refleksi

Dalam pelaksanaan kegiatan pembinaan diperoleh informasi dari hasil pengmatan sebagai berikut:

1) Siswa kurang baik dalam memotivasi siswa ketika menyampaikantujuan;

2) Siswa kurang mengefektifkan waktu; dan

3) Siswa kurang antusias selama pembinaan berlangsung.

d. Revisi Rancangan

Pelaksanaan kegiatan pembinaan pada siklus I ini masih terdapat kekurangan sehingga perlu adanya revisi untuk dilakukan pada siklus berikutnya.

1) Siswa perlu lebih terampil dalam memotivasi siswa dan Iebih jelas dalam menyampaikan tujuan pembinaan.

2) Siswa perlu mendistribusikan waktu secara balk dengan menambahkan informasiinformasi yang dirasa perlu dan memberikan catatan. Dan

3) Siswa harus Iebih terampil dan bersemangat dalam memotivasi siswa sehingga mereka bisa Iebih antusias.

\section{SIKLUS II}

a. Tahap Perencanaan

Pada tahap ini peneliti mempersiapkan peerangkat pembinaan yang terdiri dari rencana pembinaan II, soal test formatif II, dan alat-alat pembelajaran lain yang mendukung. 
b. Tahap Kegiatan dan Pelaksanaan

Pelaksanaan kegiatan untuk siklus II dilaksanakan pada tanggal 15 februari 2012 sampai dengan tanggal 16 Februari 2012 di SMA Negeri 1 Padalarang Kabupaten Bandung Barat Tahun Ajaran 20112012. Dalam hal ini Peneliti bertindak sebagai siswa mata pelajaran PPKn. Adapun proses kegiatan mengacu pada rencana kegiatan dengan memperhatikan revisi pada siklus I, sehingga kesalahan atau kekurangan pada siklus I tidak terulang lagi pada siklus II. Penelitian Tindakan Kelas ini dilaksanakan sesuai dengan porsedur rencana pembinaan dan pelaksanaan pembinaan dilaksanakan pada saat proses belajar pembelajaran berlangsung.Pada akhir proses kegiatan, siswa diberi test formatif II, dengan tujuan untuk mengetahui tingkat keberhasilan dalam proses pembelajaran. Dari tabel berikutnnya dapat dijelaskan bahwa dengan pembelajaran meletui Teknologi Pembelajaran Demonstrasional diperoleh nilai rata-rata $64.75 \%$, dan peningkatan siswa dari 20 orang siswa, baru 15 orang yang sudah tuntas (75\%), maka peneliti harus mendistribusikan waktu secara balk sehingga kegiatan penelitian dapat berjalan secara efektif sesuai dengan yang diharapkan.

\section{SIKLUS III}

a. Tahap Perencanaan

Pada tahap ini peneliti
perangkat

pembelajaran yang berkaitan dengan peningkatan prestasi belajar siswa, dengan soal tes formatif III dan alatalat pembelajaran lainnya yang mendukung.

b. Tahap Kegiatan dan Pengamatan Pelaksanaan kegiatan penelitian untuk siklus III dilaksanakan pada tanggal 17 Februari 2012 sampai dengan tanggal 18 Februari 2012 di SMA Negeri 1 Padalarang Kabupaten Bandung Barat tahun ajaran 2011 - 2012, dengan jumlah 20 orang siswa. Dari tabel dapat dijelaskan bahwa dengan pembelajaran dengan penerapan melalui Teknologi Pembelajaran Demonstrasional diperoleh nilai rata-rata 72 , dan dari 20 orang siswa semuanya telah mencapai ketuntasan, maka secara kelompok ketuntasan telah mencapai $100 \%$. Tetapi yang perlu diperhatikan untuk tindakan selanjutnya adalah memaksimalkan dan mempertahankan apa yang telah ada dengan tujuan agar pada pelaksanaan pembelajaran selanjutnya baik melalui pendekatan Teknologi Pembelajaran Demonstrasional dapat meningkatkan prestasi belajar siswa, sehingga tujuan pembelajaran sebagai upaya meningkatkan mutu pendidikan secara umum dapat tercapai.

\section{ANALISIS DATA DESKRIPTIF KUANTITATIF}

a. Pencapaian peningkatan hasil pembelajaran siswa sebelum 
kegiatan penelitian adalah : $=($ $1080 / 2000) \times 100 \%=54 \%$.

b. Peningkatan hasil pembelajaran siswa dalam pembelajaran seetelah kegiatan penelitian adalah : $=(1295 / 2000) \times 100 \%$ $=64.75 \%$.

c. Peningkatan hasil pembelajaran siswa dalam pembelajaran di kelas setelah pelaksanaan kegiatan adalah $:=(1440 / 2000)$ x $100 \%=72$.

Dari hasil analisis tersebut dapat disimpulkan bahwa:

a. Terjadi peningkatan hasil pembelajaran siswa setelah diberi penguatan melalui kegiatan gugus yaitu peningkatan hasil pembelajaran siswa dalam manajemen pengelolaan kelas: $54 \%$ menjadi $64.75 \%$ terdapat kenaikan sebesar $=10.75 \%$.

b. Dari sebelum pembinaan (siklus I) dan setelah pembinaan oleh Pembelajaran sampai dengan siklus II, $54 \%$ menjadi $64.75 \%$, dan pada siklus III, juga mengalami kenaikan yaitu sebesar : $(72 \%-64.75 \%)=$ 7.25 .

c. Rata-rata peningkatan hasil pembelajaran siswa dalam manajemen pengelolaan kelas semula hanya $20 \%$, naik menjadi $100 \%$.

\section{REFLEKSI DAN TEMUAN}

Berdasarkan pelaksanaan pembinaan yang telah dilaksanakan Pembelajaran kepada siswa melalui Teknologi Pembelajaran Demonstrasional, maka hasil observasi nilai, dapat dikatakan sebagai berikut: a. Pertemuan pertama kegiatan pembinaan belum berhasil karena dalam pembinaan Pembelajaran masih terlihat siswa belum begitu antusias, karena mereka masih menganggap pembinaan Pembelajaran tersebut merupakan tugas baru yang diembannya.

b. Pembinaan yang dilakukan melalui Teknologi Pembelajaran Demonstrasional, dalam hal peningkatan hasil pembelajaran siswa dalam pembelajaran belum Nampak, sehingga hasil yang dicapai tidak tuntas.

c. Mungkin karena proses pembinaan melalui Teknologi Pembelajaran Demonstrasional baru mereka laksanakan, sehingga para siswa merasa kaku dalam menerapkannya.

d. Setelah mendapatkan penjelasan, para siswa dapat memahaminya dengan terbukti pada pertemuan berikutnya dapat berjalan lebih baik, semua siswa aktif dan lebih-lebih setelah ada rubrik penilaian proses,semua siswa antusias untuk mengikutinya dan telah mencapai ketuntasan.

\section{HASIL DAN PEMBAHASAN}

a. Peningkatan Siswa Dalam Pembelajaran

Melalui hasil penelitian ini menunjukan, bahwa kegiatan penelitian ini memiliki dampak positif dalam meningkatkan hasil pembelajaran siswa, hal ini dapat dilihat dari semakin mantapnya kemampuan pembelajaran siswa meningkat dari siklus I, siklus II, 
dan siklus Ill, yaitu masingmasing : $54{ }^{\circ} \mathrm{A}, ; 64.75 \%$; dan $72 \%$ secara kelompok dikatakan tuntas/meningkat karena sudah mencapai ketuntasan.

b. Meningkatnya kompetensi peneliti

Meningkatkan hasil pembelajaran siswa dalam kompetensi akademik. Berdasarkan analisis data, diperoleh aktifitas siswa dalam meningkatkan hasil pembelajaran siswa dalam melaksanakan pengajaran di kelas di setiap siklusyang mengalami kemajuan.

c. Aktifitas siswa- dalam kegiatan melalui pegelolaan Teknologi Pembelajaran Demonstrasional semakin meningkat

Berdasarkan analisis data, diperoleh aktifitas para pendidik yang paling dominan dalam kegiatan penelitian adalah bekerja dengan menggunakan alat/media, mendengarkan/memperhatikan penjelasan tutor, dan diskusi antar siswa dengan komunitas pendidik yakni dalam kegiatan pemberdayaan kompetensi pendidik. Jadi dapat dikatakan bahwa aktifitas siswa dapat dikatagorikan aktif progressif, yang menunjukan bahwa aktivitas dan peningkatan kinerja para siswa cukup meningkat dalam proses pelaksanaan pembelajaran. Hal initerlihat pada pertemuan dengan 20 orang siswa yang ada saat penelitian ini dilakukan, dengan mencapai nilai rata-rata yakni $54 \%$ meningkat menjadi $64.75 \%$ pada siklus II, juga pada siklus Ill meningkat menjadi $72 \%$. Dari ananlisis data tersebut, dapat dikatakan bahwa kegiatan penelitian yang dilakukan penulis efektif untuk dapat diterapkan dalam upaya meningkatkan hasil pembelajaran siswa dalam manajemen pengelolaan kelas, yang berarti proses pembinaan pembelajaran lebih berhasil dan juga berdampak positif dalam rangka meningkatkan dan memotivasi kreatifitas dan spirit para siswa di sekolah binaannya.

\section{E. SIMPULAN DAN SARAN}

\section{Simpulan}

Berdasarkan analisis hasil penelitian dan diskusi, dapat disimpulkan sebagai berikut:

a. Pemberdayaan Teknologi Pembelajaran Demonstrasional dalam upaya meningkatkan hasil pembelajaran siswa dalam manajemen pengelolaan kelas melalui penerapan supervisi klinis menunjukan peningkatan pada setiap putaran (siklus);

b. Aktifitas dalam kegiatan pembinaan menunjukan bahwa seluruh siswa dapat meningkatkan kinerjanya dengan baik di setiap aspek;

c. Peningkatan mutu sekolah oleh Pembelajaran melalui Teknologi Pembelajaran Demonstrasional ini menunjukan peningkatan dari setiap siklusnya; dan

d. Aktivitas para siswa menunjukan bahwa kegiatan pembinaan melalui penerapan Teknologi Pembelajaran Demonstrasional bermanfaat dan dapat membantu para siswa untuk Iebih mudah 
memahami konsep, peran, dan fungsi siswa. Sehingga peningkatan kinerja para siswa dalam pembelajaran di kelasnya berjalan dengan harmonis dan menciptakan suasana proses pembelajaran yang aktif, kreatif, dan menyenangkan.

\section{Saran}

a. Penelitian perlu dilanjutkan dengan serangkaian penelitian yang mengembangkan alat ukur keberhasilan yang lebih reliable, agar dapat menggambarkan peningkatan hasil pembelajaran siswa dalam pembelajaran di kelas secara efektif dan efisien dalam mencapai mutu Pendidikan. Dan,

b. Pembinaan Pembelajaran melalui penerapan Teknologi Pembelajaran Demonstrasional diperlukan perhatian yang penuh dan disiplin yang tinggi pada setiap langkah pembinaan, dan perencanaan yang matang, misalnya dalam pengalokasian waktu dan pemilihan konsep yang sesuai.

\section{DAFTAR PUSTAKA}

Akbar, Reni dan Hawadi. 2001. Psikologi Perkembangan Anak. Jakarta: Grasindo

Ardiana, Leo India. 2003. Model-Model Penelitian. Makalah Penyegaran Guru-Guru Pembimbing Karya Ilmiah SMA di Kabupaten Mojokerto, tanggal 19 Oktober 2000 .

Budianto, Wiryawan. 1999. Pengembangan IQ dan EQ: Model Pendekatan
Pembelajaran. Jakarta: Beringin Press.

Gamal, I dan Lizna Zuniati. 1992. Pengantar Pendidikan. Jakarta: Grasindo.

Gunarsa, Singgih. 1990. Psikologi Perkembangan Anak dan Remaja; Kerangka Acuan Manajemen Lembaga Pendidikan. Jakarta: Gunung Mulia.

Kemnis, S. 1988. Rancangan Penelitian Tindakan (Terjemahan). Bandung: Asy Syifa.

Prianto, Ahmad Joko. 1995. Model-Model Pembelajaran Mata Pelajaran Pendidikan Kewarganegaraan. Dibacakan dalam Workshop Metode Pembelajaran Alternatif tanggal 02 Agustus 1995 di Malang.

Rahman, Arief. 2000. Sistem Pendidikan Indonesia: Potret Realitas Manajemen yang Mengambang. Yogyakarta: Lentera.

Sujono. 1980. Pengantar Ilmu Pendidikan Umum. Bandung CV Bina Ilmu.

Sukoco, Padmo. 2002. Penelitian Kualitatif, Metodologi, Aplikasi, dan Evaluasi. Jakarta: Gunung Agung.

Suriah, N. 2003. Penelitian Tindakan. Malang: Bayu Media Publishing.

Suryabrata, Sumadi. 1984. Psikologi Pendidikan. Bandung: Tarsita.

Suryaman, Maman. 1990. Kerangka Acuan Meningkatkan Prestasi Belajar Siswa. Bandung: Angkasa.

Suyanto, Agus. 1985. Psikologi Perkembangan. Surabaya Usaha Nasional 
Wahyudi, 1992. Sebuah Pengantar Pembelajaran di Sekolah Menengah Pertama. Bandung: Bentara Cheva.

Wibawa, B. 2003. Penelitian Tindakan Kelas. Jakarta: Dirjen Dikdasmen Direktorat Tenaga Kependidikan

Winkel, W.S. 1986. Bimbingan Belajar di Sekolah Menengah Pertama. Jakarta: Gali. 